\title{
PIONEER
}

VOLUME 11, Issue 1, June 2019: 32 - 42

\section{THE ANALYSIS OF MAIN CHARACTER'S SELF-DECEPTION AND HYPOCRISY IN THE FILM BOSS BABY}

\author{
Kholidatul Jannah \\ University of Abdurachman Saleh Situbondo \\ kholidabahri99@yahoo.com \\ Dian Maya Kurnia \\ University of Abdurachman Saleh Situbondo \\ aroundmaya86@gmail.com
}

\begin{abstract}
Self-deception was deceivers make themselves to believe something which they knew it was false, while hypocrisy was the practice of pretending to be different from what one really. Self-deception and hypocrisy were the core of this research in the filmBoss Baby. There were four research problems in this research; what were selfdeception found in thefilmBoss Baby, what kinds of hypocrisy in the film Boss Baby, what were the factors of hypocrisy found in the film Boss Baby, and what were the revelation of main characters self-deception to raise his hypocrisy. The data in this research were in the form of utterances and situations that referred to self-deception and hypocrisy in Boss Baby. This research was done by analyzing the data qualitatively. There were some steps in analyzing the data; identifying, classifying, describing, and analyzing the data. The researchers also used theory of self-deception from Mele, theory of kinds of hypocrisy from Spiegel and theory factors of hypocrisy from Lonnie Lee Best. The findings of the analysis were eleven data found by the researchers; five selfdeception, four kinds of hypocrisy (hypocrisy of pretense, hypocrisy of blame, hypocrisy inconsistency and hypocrisy of complacency), a factor of hypocrisy (carnal desires), and a datum of self-deceptionrevelation to raise hypocrisy,the boss baby actually wants a family not a position.
\end{abstract}

Keyword: self-deception, hypocrisy, film boss baby

\section{INTRODUCTION}

Literature is produced by imagination, therefore literature was an imaginative writing as prose, novel, drama, film, and etc. Roberts and Jacobs in Amalia (2012: 7) states that literature is composition that tells a story, dramatizes a situation, expresses emotions, analyzes and advocates ideas.

Film is a form of media that can influence stereotypes in society including selfdeception and hypocrisy. One part that is interesting in the literally works to study is 
hypocrisy, it is a natural characteristic of human being but when the writer put it into the character in the film, it makes the character of the film more awesome, one of films which reflect hypocrisy and self-deception is the film Boss Baby by Tom McGrath.

Boss Baby is a film directed by Tom McGrath, and written by Michael McCullers produced by Ramsey Ann Naito, narrated by Tobey Maguire and produced company by Dream Works Animation. The film tells about self-deception and hypocrisy conducted by the main character in thefilm that was the boss baby. The researchers interested in analyzing this topic because hypocrisy and self-deception often occurred in our daily life. Hypocrisy and self-deception may happen anytime, anywhere, any situation.Hypocrisy and self-deception had become a part of human life.

Base on that, the researchers conducted this research based on some research problems and objectives. The research problems were what are self-deception in the film Boss Baby? What kinds of hypocrisy found in the film Boss Baby? What are the factors of hypocrisy found in the film Boss Baby? And what are the revelation of main characters self-deception to raise his hypocrisy? Moreover, the objectives of this study were to found self-deception, kinds and factors of hypocrisy, and revelation of main characters to raise his hypocrisy in the film Boss Baby.

Character is one of the important elements in life like as in the film, because there will be no film if there was no character. According to Eder (2008:17), character is highly controversial. Most frequently, they tend to be considered as imaginary human beings. Henderson in Pamela (2011: 6) states that character refers to the people authors create to inhabit their stories. Characters should be believable and consistent. Being believable means not that all characters be like people we have known but they believable in the context of the story. Consistently requires not that the characters remain exactly the same, but that any changes in character be sufficiently by what happens to them in a story. Laughlin in Pamela (2011:1) states that character is the term for the people in the fiction, the heroes and villain, allies, and enemies, love interest and comic reliefs. Character can be divided into two, main character (major character) and supporting character (minor character). 


\section{Main Character}

The main character in a story was generally known as the protagonist, the character who opposes him or her was the antagonist. Character was revealed by how a character responds to conflict, by his or her dialogue, and through descriptions. The protagonist was the main character in a story, novel, drama, or other literary work, the character that the reader or audience empathizes. Henderson, Mason, Day, and Waller in Pamela (2011:2) state that the major characters are round characters usually, that is, their personalities are well developed and believable, these characters frequently change as the story progresses; if they do, they were also described as dynamic. Minor character were often flat characters we saw only one aspect of their personalities, presumably because the author does not need to reveal about the more for the purposes of the story. Flat character usually static characters, that was, they do not change.

\section{Value}

According to Oysterman (2001: 16150) values are difficult to study andpersistent questions arise as to whether they are 'real', whether they actually can be showed to have causal influence on behavior. Yet much of everyday life was cast in terms of values - think of ethics, law, religion, politics, art, child rearing, and more. Abstract value judgments were embodied in seeming gut reactions that something was right, moral, or natural vs. wrong, immoral, or unnatural.

\section{Self-Deception}

According to Grenberg (2015:163), self-deception is that inner lies occur, but the very notion of an inner lie involves a contradiction which seems to make it impossible for them to occur. Barnes argues that in self-deception, self-deceivers must intentionally get themselves to believe something they know or truly believe is false (Barnes 1997: 4 in Widyaningrum 2014). It means that self-deception only involved one person, she or he was not only as deceiver but also deceived. Itwas the difference between interpersonal deception and self-deception, that in interpersonal deception, one intentionally got the other one to believe something, but in self-deception, deceivers intentionally get themselves to believe something. (Mele 1987: 122 in Widyaningrum2014). Deceiving someone else is to make the other person believe 
something that the deceiver knows it was false. While in self-deception, deceivers make themselves to believe something which they know it was false. Self-deception involves just one person, where she or he was not only become deceiver but also deceived.

\section{Hypocrisy}

People do something because they have a motive. Everything which was did by them was a sign of their motive or the aim they have. When they want to get attention from others, they tend to did something which can make the other people give them attention. It can be done by the people who did not intend to deceived. They did something which was consistent with their motive. Deceit is done by the signs of outward deeds. Such as when a person pretends to have a good purpose or intent through their actions, but in reality, it was a bad goal. Alicke, Gordon, and Rose (2012:1) state that hypocrisy is a multifaceted concept that has been studied empirically by psychologists and discussed logically by philosophers. According to Hornby in Anitasari (2010:25) hypocrisy is the practice of pretending to be different from what one reallyis.

\section{Kinds of Hypocrisy}

Roger Crisp and Christopher Cowton offers a fourfold distinction of the vice, which are Spiegel (1999: 30) in Widyaningrum (2014), they are hypocrisy of pretense, hypocrisy of blame, hypocrisy of inconsistency, and hypocrisy of complacency.

The hypocrisy of pretense occurs when a person puts up a front of being morality or physically better than he is.Hypocrisy of blame, defined as moral criticism of others by someone with moral fault of their own. The vice often appears to lie particularly in the fact that the fault of the critic was worse than criticized (Spiegel, 1999: 31).

The third category of hypocrisy was that inconsistency, which was defined as the uttering of some (overriding) moral requirement that does apply to oneself and then failing to live up to it. Hypocrisy of inconsistency occurs when a person's action was not in accordance to his words. For example: A person told to his friend that he would read a novel but then the other friend of this person saw that he was not reading a novel but he was playing apiano. 
Lastly, complacency in certain conditions can be said a form of hypocrisy. To be guilty of this was to ignore the demands of morality when they become costly, to be content with one's moral status, refused to improve or even to reflect upon it, while carried on a pretense of virtue blamed others for they vice, or failing to practice what one preaches.

\section{Factors of Hypocrisy}

Lonnie Lee Best (2006:8) divides the hypocrisy into three general factors: 1) Uncertainty of beliefs: If you are not $100 \%$ certain in what you believe, then your actions were not likely to be consistent with your beliefs $100 \%$ of the time. A conservative interpreter of reality was seldom $100 \%$ certain about anything. This uncertainty can cause one to be hypocritical attimes. 2) Carnal desires: These were inherent human desires that often cause one to act on what the flesh desires, rather than what one believed to be the right action. 3) The difficulty level of the belief system: If one's belief standards of right and wrong were higher than what is humanly possible, then their actions are obviously not going to be consistent with their beliefs.

\section{Synopsis of Film Boss Baby}

Tim Templeton has the most amazingly perfect life ever. With his loving parents to himself he doesn't realize his mother was pregnant. But when his new little brother comes along, Tim anxiously looked out the window to see his parents returned in a taxi with their new baby. He started getting less attention. Tim sneaks into boss baby's room that night and hears him spoke with the voice of a grown man on the phone. He appears to be conspiring with someone until Tim catches him and forces boss baby to admit that he can talk. Although Tim thinks he was got something on him, boss baby was unfazed and pulls out a file on Tim, stating he knew things like how Tim's middle name was Leslie. Boss baby warns Tim that if he doesn't shape up, his parents can "fire" him. Boss baby has been sent by baby corps to investigate and put an end to Puppy Co, an organization that was launched a forever puppy to replace babies, Tim tried to told his parent about the secret to the boss baby but the plan was always thwarted by the boss baby. Boss baby tried to focus on his mission.In the end, Tim and boss baby worked to thwart plans evil CEO Puppy Co. 


\section{METHODOLOGY}

In this study the researchers used qualitative research. Qualitative research was a research procedure that produced descriptive data such as a text, statement and human's behavior that become the object of research. Descriptive qualitative was one of the types of research included in this type of qualitative research. According to Vickie (2012:255), the goal of qualitative descriptive studies was a comprehensive summarization in everyday terms, of specific events experienced by individuals or groups of individuals. Cresswell (2009: 4) states that individuals or group ascribe to a social or human problem. The researchers used qualitative approach and content analysis as the research design which was analyzed the relation among sentence or words that produced particular meaning.Descriptive qualitative method was a process ofresearch data collection. In this case the researchers collected the whole of the data related to main character self-deception and hypocrisy in the film Boss Baby.

The researchers collected the data from a film entitled Boss Baby (2017). Then the research data were in the form of utterances, action, and situation of the character which indicated self-deception and hypocrisy. Instrument of this research was observation check list used Mele's theory and Spiegel's theory. The researchers did the observation during watching the film. The data were collected used document analysis. There were some steps of collecting the data in order to complete this research, they are watching the film Boss Baby, screen capturing the scene with action, utterances, and situation indicated self-deception and hypocrisy, inventorying data (nothing down the action, utterances, and situation) which was indicated self-deception andhypocrisy.

To analyze the data, the researchers used some theories from experts. There were some steps to analyze the data, identify the data on the main character selfdeception and hypocrisy in the film Boss Baby, classify the data based on the main character self-deception and hypocrisy in the film Boss Baby, describe the impact of self-deception used theory from Mele (1987), describe the impact used the theory from Spiegel (1999), analyze the factors of hypocrisy used the theory from Lonnie Lee Best, draw the conclusion about the types of self-deception and hypocrisy in the film Boss Baby. 


\section{FINDING AND DISCUSSION}

\section{Self-Deception}

\section{Datum 01}

Mr.Francis stop Tim and boss baby when they save their parents.

Tim : "No, I'm nothing likeyou."

Mr.Francis : "Bratty kid"

Baby boss : "Let our parents go! His parents. The parents."

Self-deception was deceivers make themselves to believe something which they knew it was false. The boss baby lies to himself that he has parents, by changing the words 'our parents' to 'his parents'. In the situation boss baby did self-deception theory from Mele (1987: 122).

\section{Datum02}

After Tim and boss baby save his parents.

Mom : "We love you both so much."

Tim : "Both of us?"

Mom : "With all our heart."

The boss baby smiles and silent.

Self-deception was deceivers make themselves to believe something which they knew it false. The boss baby deceived to himself that he was happy and has a family. He felt protect as child. In the situation boss baby done self-deception theory from Mele (1987: 122).

\section{Datum 03}

In the taxy the baby felt sad separate with Tim.

Self-deception was deceivers make themselves to believe something which they knew it was false. The boss baby deceived to himself that he doesn't happy and don't want to leave Tim and his parents, he loved them. In the situation boss baby did selfdeception theory from Mele (1987: 122).

\section{Datum 04}

Boss baby sat on the toilet with a sad face, remembered Tim.

Self-deception was deceivers make themselves to believe something which they knew it was false. The boss baby deceivers himself that he missing Tim. In the situation, boss baby done self-deception theory from Mele (1987: 122). 


\section{Datum06}

Tim : "What? You've never been tick led? What about your parents?" The boss baby silent, bowed with a sad face.

Tim : "Oh! I'm sorry, I forget you didn't have parents, did you!"

Self-deception was deceivers make themselves to believe something which they knew it was false. The boss baby deceived himself that he does not want family when Tim said about parents, boss baby's parents, boss baby saw sad and silent. In the situation boss baby did self-deception theory from Mele (1987: 122).

\section{Hypocrisy}

\section{Datum 01}

Tim came down from the stairs looked his parent with baby boy.

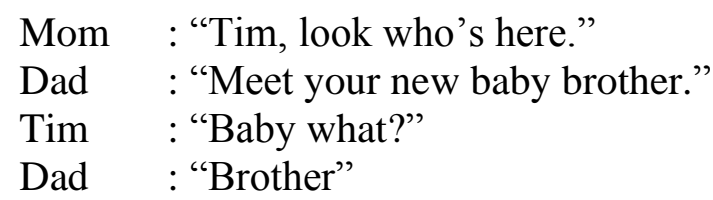

Tim showed an annoyed face to boss baby, Tim have a million question in his mind. Who's this guy? Why is he here? What's with that outfit? Why he so fat? Why's he staring at me. Does he know karate? What's going on? The boss baby saw Tim didn't like his presence. Suddenly, the boss baby swiped the middle finger with thumb, then cried to get his parents'attention.

Hypocrisy of inconsistency occurred when a person's action was not in accordance to his words. In the filmboss baby, when boss baby saw Tim didn't like his presence, the boss baby swiped the middle finger with thumb then cried to get attention from his parents. In the situation, boss baby done hypocrisy of inconsistency theory from Spiegel (1999:30).

\section{Datum 02}

When Tim said "He carries a briefcase". The boss baby hides his briefcase.

Hypocrisy of inconsistency occurred when a person's action was not in accordance to his words. When Tim told his parents that the boss baby was carried a suitcase, boss baby hides a suitcase, in order to the parents don't know that the boss baby wasn't an ordinary baby. In the situation the boss baby done hypocrisy of 
inconsistency theory from Spiegel (1999:30).

\section{Datum 03}

When the babies in a meeting and the twins baby said to boss baby.

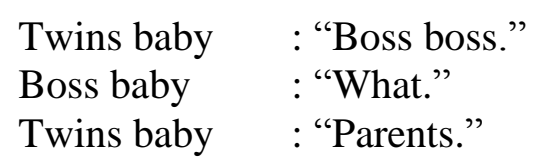

Hypocrisy of inconsistency occurred when person's action was not in accordance to his words. When thebaby told meetings about destroyed Puppy Co. their parents came, suddenly a baby stopped the meeting and started played. In the situation, the boss baby does hypocrisy of inconsistency theory from Spiegel (1999:30).

\section{Datum 04}

The boss baby ripped the Tim's do because he grabbed a tape. Tim angry, brought boss baby to cradle and bounce out of the house. Suddenly, their parents came.

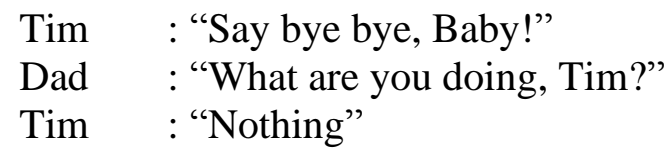

Hypocrisy of inconsistency occurred when a person's action was not in accordance to his words. When Tim brought boss baby to bounce out of the house. Suddenly his parents came scolded and punished to Tim for his actions tothe boss baby. In situation the boss baby done hypocrisy because his acted was not accordance to his word when his parents come, the boss baby such as not involved in that, it was hypocrisy of inconsistency theory from Spiegel (1999:30).

\section{Datum 05}

The boss baby picks up the phone and cried loudly, until his parents came to brought dolls and toys to match it.

$$
\begin{aligned}
& \text { Mom : "You called?" } \\
& \text { Dad : "Do you need senatorsqueaky?" }
\end{aligned}
$$

Hypocrisy of inconsistency occurred when a person's action was not in accordance to his words. When boss baby cries loudly made his parents anxious and tired. In situation the boss baby did hypocrisy because his acted was not accordance to his word. It was hypocrisy of inconsistency theory from Spiegel (1999:30) 


\section{The Factors of Hypocrisy}

\section{Datum 01}

The baby accept mission to broke Puppy Co.

Explanation:

The baby wants to be a boss in his office Baby Corp.

\section{CONCLUSION AND SUGGESTION}

Based on the finding and discussion, the researchers concludedsome points about the main character's self-deception and hypocrisy in the filmBoss Baby. This study only focused on self-deception and hypocrisy.This research found some selfdeceptions, kinds and factors of hypocrisy. Besides, the researchers also found revelation of main characters self-deception to raise his hypocrisy in the film Boss Baby.

Some differences had been found by the researchers from the three gaps of this research.The differences that found in the first gap were that the researcher of the research focused on social status, while this research focused on self-deception and hypocrisy.The differences of this research with the second gap was focused on sociological analysis.In addition, the researchers differed this research with the thirdgap in term of morality reflected in this research wereself-deception andhypocrisy.

In the analysis of self-deception and hypocrisy in the film Boss Baby, the researcher realized that this research was needed to be continued by the next researchers, this research still has weaknesses. Thus, the researcher suggested the next researcher to find the new object other than the film Boss Baby to analyze selfdeception and hypocrisy to improve the research quality. The researchers hoped this research give an inspiration to the readers to continue this research on self-deception and hypocrisy.

\section{REFERENCES}

Amalia M, Rifa Restu. (2012). Tokoh Utama dalam Novel Harry Potter and the Prisioner of Azkaban Karya J.K. Rowling: Sebuah Kajian Kesusastraan. Universitas Widyatama Bandung.

Anitasari, Nurin. (2010). Arthur Dimmesdale's Hypocrisyasa Puritan Clergyman in Nathaniel Hawthorne's The Scarlet Letter (A Sociological Approach). Sebelas 
Maret University Surakarta.

Mayasari, Fitria. (2011). Hypocrisy among the Upper Class in Oscar Wilde's Lady Windermere's Fan (1892): A Sociological Approach. Muhamadiyah University of Surakarta.

Nurhasanah, Hanifah (2017). Hypocrisy of Victorian Morality Reflected in a Woman of No Importance (1893) By Oscar Wilde: A Sociological Approach. Muhammadiyah University of Surakarta.

Eder, Jens (2008). Understanding Characters. Germany.

Famela. (2011). An Analysis of the Main Character on the Film Amazing Grace by Michael Apted. Syarif Hidayatullah Jakarta.

Oyeserman, D. (2001). Value: Pshycologycal Perspectives. International Encyclopedia of the Social \& Behavioral Sciences.

Schwartz, Shalom H. (1994). Values and Personality. European Journal of Personality, Vol. 8, 163-181.

Grenberg, Jeanine M. (2015). Self-deception and Self-knowledge: Jane Austen's Emma as an Example of Kant's Notion of Self-Deception. International Journal of Philosophy.

Widyaningrum, Ayu. (2014). Ivan's Self-deception and Hypocrisy in Leo Tolstoy's The Death of Ivan Ilych. State University of Surabaya.

Rose D, Gordon E, Alicke M. (2012). Philosophical Hypocrisy. Ohio University Libraries.

Best, Lonnie L. (2006). “The Hard Core Truth: Are You a Hypocrite?”. Journal of Phylosophy (2006), [e-Journal], http://www.hardcoretruth.com/hypocroisy/.htm> (accessed on 7 November 2006).

Vickie A, Clinton E, (2012). Qualitative Descriptive Research: An Acceptable Design. Pacific Rim International Journal of Nursing Research.

Cresswell, John W. (2009). Research Design: Qualitative, Quantitative, and Mixed Methods Approaches. University of Nebraska-Lincoln. 